Shintõ and the State, 1868-1988 


\section{Studies in Church}

and State

JOHN F. WILSON, EDITOR

The Restructuring of American Religion: Society and Faith Since World War II by Robert Wuthnow

Shinto and the State, I868-I988

by Helen Hardacre 


\title{
Shintō
} and the State, 1868-1988

\author{
Helen
}

Hardacre

PRINCETON

UNIVERSITY

PRESS 
Copyright (C) 1989 by Princeton University Press

Published by Princeton University Press, 4I William Street,

Princeton, New Jersey o 8540

In the United Kingdom: Princeton University Press, Chichester, West Sussex

All Rights Reserved

First paperback printing, 1991

This book has been composed in Linotron Galliard text and Optima Bold Display type

On the title page: The Gate of the Yasukuni Shrine

Princeton University Press books are printed on acid-free paper, and meet the guidelines for permanence and durability of the Committee on Production Guidelines for Book Longevity of the Council on Library Resources

Library of Congress Cataloging-in-Publication Data

Hardacre, Helen, 1949-

Shintō and the state, I868-1988 / Helen Hardacre.

p. $\mathrm{cm}$.- (Studies in church and state)

Bibliography: $p$.

Includes index

ISBN O-69I-07348-I

ISBN 0-69I-02052-3 (pbk.)

I. Shinto and state. 2. Shinto-History-1868-1945.

3. Shinto-History-1945- I. Title. II. Series.

BL2223. $58 \mathrm{H} 361989$

$322^{\prime} . \mathrm{I}-\mathrm{dcI9} \quad 88-35665$

$\begin{array}{llllll}8 & 7 & 6 & 5 & 4 & 3\end{array}$

Printed in the United States of America 
For Yōko 
